\title{
Pembinaan Anak yang Berkonflik dengan Hukum Dari Perspektif Restorative Justice (Studi Perbandingan Antara Indonesia dengan Malaysia)
}

\author{
Fatriansyah \\ Program Magister Ilmu Hukum, Universitas Batanghari, \\ Jl. Ibrahim Ripin 1 RT.33 Blok I No.9 \\ Correspondence email: drfatriansyah.gmail.com
}

\begin{abstract}
Abstrak. Tujuan penelitian ini adalah 1) Untuk menemukan dan menganalisis kelembagaan yang berwenang menangani pembinaan anak yang berkonflik dengan hukum di Indonesia dengan Malaysia, dan 2) Untuk menemukan dan menganalisis pembinaan anak berkonflik dengan hukum di Indonesia dan Malaysia dari persepktif retorative justice. Adapun permasalahan pokoknya adalah 1) Bagaimana kelembagaan yang berwenang menangani pembinaan anak berkonflik dengan hukum di Indonesia dengan Malaysia, dan 2) Bagaimana pembinaan anak berkonflik dengan hukum di Indonesia dan Malaysia dari persepktif retorative justice. Metode penelitian yang digunakan adalah penelitian hukum normatif. Pendekatan yang digunakan adalah pendekatan undang-undang, historis, perbandingan hukum dan konseptual. Hasil dari penelitian ini adalah 1) Lembaga pembinaan yang menangani anak yang berkonflik dengan hukum kedepannya harus mempertimbangkan penghormatan harkat dan martabat anak dalam bentuk perspektif struktur dan infrastruktur di lembaga pembinaan dengan kata lain lembaga pembinaan layak anak. Selanjutnya untuk memberikan perlindungan dan kebutuhan hak orang tua lembaga pembinaan anak yang berkonflik dengan hukum perlu menyiapkan hak bagi orang tua atau wali anak yang akan bertemu dan berkunjung. Selain itu dari sudut estetika dan arsitektur bangunan Lembaga pembinaan bagi anak yang berkonflik dengan hukum harus ramah anak, agar tidak terstigma seperti penjara atau lembaga pemasyarakatan umumnya bagi orang dewasa. 2) Pembinaan bagi anak berkonflik dengan hukum pada saat ini hanya menjadi tugas dan tanggungjawab pihak pembina dalam lembaga, pelaku tindak pidana dan masyarakat saja, sehingga restorative justice tidak tercapai. Kedepannya pembinaan anak yang berkonflik dengan hukum di Indonesia perlu menggunakan pendekatan keadilan restoratif, dalam setiap tahap pembinaannya dengan demikian pembinaan bagi anak yang berkonflik dengan hukum tidak hanya berorientasi pada rehabilitasi dan resosialisasi pada pelaku tindak pidana saja tetapi juga pemulihan terhadap korban dan kehidupan masyarakat.
\end{abstract}

Kata Kunci: Pembinaan, Anak Berkonflik Dengan Hukum

Abstract. The purposes of this study are 1) To find and analyze institutions authorized to deal with children in conflict with law in Indonesia and Malaysia, and 2) To find and analyze the process of fostering children in conflict with law in Indonesia and Malaysia. The main problems discussed in this study are 1) Guidance institutions that deal with children in conflict with the law in the future must consider respect for the dignity of children in the form of structural and infrastructure perspectives in coaching institutions in other words a child-friendly coaching institution. Furthermore, to provide protection and the needs of the rights of parents of child development institutions in conflict with the law, it is necessary to prepare the rights for parents or guardians of children who will meet and visit. In addition, from the aesthetic and architectural point of view of building institutions for children in conflict with the law must be child-friendly, so as not to be stigmatized such as prisons or correctional institutions generally for adults. 2) Guidance for children in conflict with the law at this time is only a duty and responsibility of the supervisor in the institution, criminal offender and the community alone, so that restorative justice is not achieved. In the future, the development of children in conflict with law in Indonesia needs to use a restorative justice approach. In each stage of its development, guidance for children in conflict with the law is not only oriented to rehabilitation and resocialization of perpetrators but also recovery of victims and people's lives.

Keywords: Children of Rehabilitation in Conflict with The Law

\section{PENDAHULUAN}

Anak sebagai manusia yang masih kecil, sedang tumbuh dan berkembang, baik fisik mental maupun intelektualnya. Pada masa perkembangan tersebut setiap anak sedang berusaha mengenal dan mempelajari nilai-nilai yang berlaku di masyarakat serta berusaha meyakini sebagai bagian dari dirinya. Sebagian kecil anak tidak dapat memahami secara utuh aturan hidup di dalam masyarakat baik disebabkan oleh kurangnya perhatian orang tua, kurang kasih sayang, kurang kehangatan jiwa, adanya kekerasan di dalam keluarga dan masyarakat yang membawa dampak pada terbentuknya sikap dan perilaku menyimpang anak di masyarakat. Sebagian perilaku menyimpang anak-anak 
tersebut akan bersentuhan dengan ketentuan hukum. Anak-anak inilah yang disebut anak yang berkonflik dengan hukum. ${ }^{1}$

Berdasarkan Peraturan Minimum Standar Perserikatan Bangsa-Bangsa Mengenai Administrasi Peradilan Bagi Remaja (Beijing Rules). tujuan peraturan ini dibuat agar negara-negara anggota agar dapat menyesuaikan dengan sistem dan konsep hukum masing-masing negara terkait pengertian anak dan pelanggar hukum. Kemudian fokus tulisan ini adalah anak yang berkonflik dengan hukum (selanjutnya disebut anak) sebagai pelaku tindak pidana. Anak yang berkedudukan sebagai pelaku disebut dengan anak yang berkonflik dengan hukum. Jika dilihat dari penjelasan tersebut, Undang-Undang mengisyaratkan tentang kemampuan anak dalam berkonflik dengan hukum adalah antara umur 12 (dua belas) tahun sampai dengan 18 (delapan belas) tahun, hal ini dimungkinkan mengingat perkembangan emosi anak lebih stabil dibanding anak dibawah umur 12 (dua belas) tahun, akan tetapi peradilan pidana perlakuan terhadap anak tetap harus dibedakan dengan perlakuan orang dewasa.

Anak yang berkonflik dengan hukum disebabkan karena pelanggaran terhadap hukum atau tindak kriminal yang diperbuatnya. Pengertian tersebut menunjukkan pentingnya peranan nilai atau norma dalam suatu masyarakat yang menjadi bagian dari hukum yang ditetapkan oleh suatu negara. Namun lebih luas lagi bahwa anak yang berhadapan dengan hukum adalah anak yang melanggar nilai atau norma dalam masyarakat. Sehingga keterpisahan anak dari nilai atau norma dalam suatu masyarakat termasuk di dalamnya adalah nilai atau norma keluarga merupaan indikator awal pelanggaran hukum. ${ }^{2}$

Kasus hukum yang melibatkan anak-anak sebagai pelaku kejahatan memang membutuhkan penanganan khusus mengingat sebagai subjek hukum, anak-anak belum terikat hak dan kewajiban yang sepenuhnya mengikat. Anak-anak dianggap belum mampu menyadari akibat dan konsekuensi dari perbuatannya yang melanggar hukum dan memungkinkan terjadinya kerugian, ketidak seimbangan dan disharmoni dalam kehidupan bermasyarakat, berbangsa dan bernegara. Begitu banyak konsekuensi yang harus anak-anak itu terima akibat dari perbuatan yang mereka lakukan tanpa mereka menyadarinya. ${ }^{3}$ Namun demikian hukum tetaplah hukum, semua orang memiliki hak yang sama dihadapan hukum dan hal tersebut harus diterima sebagai bentuk perwujudan persamaan hak dimuka hukum bagi setiap warga negara Indonesia. ${ }^{4}$

Perlakuan terhadap anak yang berkonflik dengan hukum perlahan berubah seiring dengan berlakunya UndangUndang Nomor 11 Tahun 2012 tentang Sistem Peradilan Pidana Anak. Menandai perubahan tersebut, pemerintah mengubah Lembaga Pemasyarakatan Anak (LPA) menjadi Lembaga Pembinaan Khusus Anak (LPKA). ${ }^{5}$

Selama anak dalam proses pembinaan di Lembaga Pembinaan Khusus Anak (LPKA), maka anak narapidana berhak memperoleh pembinaan, pembimbingan, pengawasan, pendampingan. Sejalan dengan hal di atas Marlina mengatakan bahwa:

Sejak lahirnya Undang-Undang Nomor 11 Tahun 2012 tentang Sistem Peradilan Pidana Anak, sampai dengan saat ini tidak dilengkapi berbagai peraturan turunannya. Dengan demikian dapat dikatakan bahwa Undang-Undang Nomor 11 Tahun 2012 tentang Sistem Peradilan Pidana Anak memiliki kelemahan yaitu sampai dengan saat ini tidak ada Peraturan Pemerintah dan peraturan lainnya baik itu Petunjuk Teknis maupun Petunjuk Pelaksanaan terhadap Undang-Undang tersebut.

Program pembinaan bagi anak yang berkonflik dengan hukum di Lembaga Pembinaan Khusus Anak (LPKA) sampai saat ini masih menggunakan program pembinaan sebagaimana termaktub di dalam Undang-Undang Nomor 12 Tahun 1995 tentang Pemasyarakatan. Bahwa setiap Warga Binaan Pemasyarakatan yang terdiri dari narapidana dan anak didik diberikan pembinaan dan pembimbingan kepribadian dan kemandirian oleh pihak Lembaga Pemasyarakatan. Artikata pembinaan yang diberikan untuk Warga Binaan Pemasyarakatan dewasa dan anak sama, tidak ada perbedaan.

Idealnya pembinaan terhadap anak yang berkonflik dengan hukum dibedakan dengan pembinaan terhadap Warga Binaan Pemasyarakatan dewasa mengingat kondisi anak tidak sama dengan orang dewasa. Hal ini sejalan dengan yang dikatakan oleh Muncie:

That the main thing that underscores the emergence of special handling for children facing the law is the awareness that children need a response that is different from the response given to adults who violate the law

\footnotetext{
${ }^{1}$ Aep Rusmana, “Alternatif perlindungan Anak yang Berkonflik Dengan Hukum”, Jurnal Pusdiklat Kesos, Volume 1, Bandung, (Agustus 2008).

${ }^{2}$ Alit Kurniasari dkk, Studi Penanganan Anak Yang Berkonflik Dengan Hukum, Puslitbang Kessos, Depsos Republik Indonesia, 2007, hal. 10.

${ }^{3}$ Hadi Utomo, Anak Yang Berkonflik Dengan Hukum, (Jakarta: Yayasan Bahtera-Unesco-Unicef, 2010), hlm. 5.

${ }^{4}$ Ibid.

${ }^{5}$ Ibid.
} 
(Bahwa hal utama yang menggarisbawahi munculnya penanganan khusus bagi anak-anak yang berhadapan dengan hukum adalah kesadaran bahwa anak-anak memerlukan respon yang berbeda dengan respon yang diberikan kepada orang dewasa yang melanggar hukum). ${ }^{6}$

Program pembinaan intelektual berupa pendidikan bagi anak-anak yang berada di Lembaga atau institusi penjara semestinya berjalan maksimal hal ini sesuai dengan amanat yang terdapat dalam Undang-Undang Nomor 11 Tahun 2012 tentang Sistem Peradilan Pidana Anak. Dengan berlakunya Undang-Undang Nomor 11 Tahun 2012 tentang Sistem Peradilan Pidana Anak, struktur dalam Lembaga Pembinaan Khusus Anak (LPKA) berubah dan lebih menitik beratkan pada pembinaan pendidikan. Menciptakan tempat berbasis pendidikan. Yang tak kalah pentingnya seharusnya setiap Lembaga Pembinaan Khusus Anak (LPKA) memiliki tenaga Psikolog, namun dalam kenyataannya sampai dengan saat ini tidak ada Psikolog dalam Lembaga Pembinaan Khusus Anak (LPKA) di Indonesia. Psikolog ini diperlukan untuk penanganan anak yang berkelakuan khusus dan program pembinaan yang tepat. Hal ini sejalan dengan apa yang ditemukan oleh Pusat Kajian Kriminologi Universitas Indonesia:

Anak-anak dalam Lembaga Pemasyarakatan tetap merasakan dan mengalami kekerasan, baik kekerasan fisik dan verbal, serta kekerasan psikologis baik yang diterima oleh sesama penghuni maupun dari petugas. Perkembangan yang memperihatikan adalah dijumpainya anak-anak yang memperlihatkan perilaku orang mengalami gangguan jiwa seperti berteriak-teriak sepanjang hari dan malam, mengamuk dan mengalami depresi dan stres. Selain itu juga dijumpai petugas yang mengalami gangguan perilaku seperti bicara sendiri terus menerus, ikut campur dalam pembicaraan tanpa sebab, berjalan mondar mandir tanpa tujuan sambil berbicara keras. ${ }^{7}$

Dari penjelasan di atas, dapat dijelaskan secara normatif pembinaan anak yang berkonflik dengan hukum berdasarkan Undang-Undang Nomor 11 Tahun 2012 tentang Sistem Peradilan Pidana Anak, namun dalam pelaksanaannya pembinaan anak yang berkonflik dengan hukum masih mengadopsi program pembinaan dalam Undang-Undang Nomor 12 Tahun 1995 tentang Pemasyarakatan. Dengan demikian dapat dikatakan pertentangan norma pembinaan yang dilakukan dalam peraturan perundang-undangan bagi anak yang berkonflik dengan hukum.

Selanjutnya penulis melakukan pendekatan secara perbandingan terkait kerangka hukum yang mengatur pembinaan anak yang berkonflik dengan hukum, lembaga yang menangani anak berkonflik dengan hukum dan proses pembinaan anak berkonflik dengan hukum dengan Negara Malaysia terkait pembinaan bagi anak yang berkonflik dengan hukum.

Sebelum dijelaskan program pembinaan yang dilakukan bagi anak-anak yang berkonflik dengan hukum di Malaysia terlebih dahulu dijelaskan sejarah terbentuknya lembaga atau institusi pembinaan atau penjara bagi anakanak di Malaysia. Adapun sejarah berdirinya lembaga atau penjara bagi anak di Malaysia yaitu berkisar pada abad ke 18, keluarga merupakan faktor penyebab utama bagi anak melakukan kejahatan atau anak berkonflik dengan hukum. Berawal dari anggapan tersebutlah, maka Malaysia mendirikan lembaga atau penjara bagi anak-anak. ${ }^{8}$

Pada abad ke 19 didirikan lembaga atau penjara pembinaan bagi anak yang berkonflik dengan hukum. Lembaga ini bertujuan untuk membawa kehidupan anak-anak dan keluarganya menjadi suatu model institusi pembinaan bagi anak-anak di Malaysia. Lembaga atau penjara dijadikan sebagai rumah bagi anak-anak, anak-anak yang berada dalam lembaga atau penjara dijadikan sebagai keluarga dan pegawai lembaga dijadikan sebagai orang tua bagi anak-anak yang berada di dalam Lembaga atau penjara tersebut. ${ }^{9}$

Selanjutnya kerangka hukum yang mengatur untuk anak-anak yang berkonflik dengan hukum diatur dalam Akta Kanak-Kanak 2001, di dalam Akta Kanak-Kanak 2001 ini membagi membagi 3 (tiga) tempat tahanan bagi anakanak yaitu 1. Asrama Akhlak, 2. Sekolah Diluluskan/Sekolah Tunas Bakti (STBs); dan 3. Sekolah Henry Gurney (SHG). ${ }^{10}$

Pengaturan tentang Asrama Akhlak ini diatur dalam Akta Kanak-kanak 2001 dalam Pasal (Seksyen) 61 sampai dengan Pasal (Seksyen) 64. Asrama Akhlak ini merupakan institusi bagi tahanan anak sementara dan tahanan yang bermasalah dengan tingkah laku sebelum dipindahkan ke Sekolah Tunas Bakti. Bagi anak yang berkonflik dengan hukum yang berumur dibawah 10 (sepuluh) tahun tidak dibenarkan untuk dimasukkan ke Asrama Akhlak.

Adapun bentuk-bentuk pembinaan yang diberikan di Asrama Akhlak adalah penjagaan dan perlindungan, kaunseling dan bimbingan, akademik, pendidikan agama atau moral serta keterampilan/kejuruan dan rekreasi/olah raga). Tahanan anak berada di asrama akhlak tidak lebih dari 12 (dua belas) bulan untuk tahanan anak yang berhadapan dengan hukum atau anak-anak yang bermasalah dengan tingkah laku. Sementara untuk tahanan anak

${ }^{6}$ Jhon Muncie, Youth and Crime A Critical Introduction, (London:Sage Publibation, 1999), page. 23.

${ }^{7}$ Dinar Kania dan Ahmad Alim, "Stategi Pembinaan Pendidikan Berbasis Psikologi Pendidikan", Artikel (30 September 2012): 10 .

\footnotetext{
${ }^{8}$ Ibid

${ }^{9}$ Ibid.

${ }^{10}$ Ibid.
} 
sementara dipindahkan ke Sekolah Diluluskan/Sekolah Tunas Bakti tidak boleh lebih dari 2 (dua) minggu, melalui perintah Mahkamah Kanak-Kanak. ${ }^{11}$

Selanjutnya Sekolah Tunas Bakti adalah institusi untuk penanganan anak yang berkonflik dengan hukum. Institusi ini diatur dalam Akta Kanak-Kanak 2001 pada Pasal (Seksyen) 65 sampai dengan Pasal (Seksyen) 72. Anak yang berkonflik dengan hukum yang masuk ke Sekolah Tunas Bakti adalah anak yang berumur 10 (sepuluh) tahun ke atas, untuk anak yang berumur dibawah 10 (sepuluh) tahun tidak boleh dimasukan ke dalam Sekolah Tunas Bakti.

Adapun pembinaan yang diberikan pada Sekolah Tunas Bakti ini antara lain penjagaan dan perlindungan, konseling dan bimbingan, akademik, pendidikan agama/moral dan keterampilan/kejuruan dan rekreasi/olah raga. Waktu bagi anak yang bermasalah dengan hukum untuk dibina pada Sekolah Tunas Bakti ini hanya sampai dengan 3 (tiga) tahun. ${ }^{12}$

Kemudian, Sekolah Henry Gurney (SHG) adalah institusi untuk anak yang berkonflik dengan hukum yang berumur 14 (empat belas) tahun sampai dengan 21 (dua puluh satu) tahun. Sekolah Henry Gurney (SHG) ini diatur dalam Akta Kanak-kanak 2001 pada Pasal (Seksyen) 73-75. Program pembinaan yang dilakukan di Sekolah Henry Gurney (SHG) antara lain:

1. Program Orientasi, program ini berlangsung selama 3 (tiga) bulan yang meliputi:

a. Induksi ( 7 hari), yaitu penerimaan, pendaftaran orientasi, sesi temuduga, sesi taklimat, sesi pemeriksaan kesihatan, kebersihan, sukan dan rekreasi.

b. Orientasi (75 hari), yaitu latihan fizikal, aktiviti kenegaraan, aktiviti kemahiran sosial, kerohanian, kaunseling, ujian air kencing (tes urin), ujian HIV/Aids (tes HIV/Aids), kebersihan, sukan dan rekreasi.

c. Penilaian (7 hari), yaitu modul fizikal, modul ketata negaraan modul kemahiran sosial, modul kerohanian, modul kaunseling, kebersihan, modul sukan dan rekreasi, dan disiplin diri.

2. Pengukuhan Sahsiah selama 6 (enam) bulan sampai dengan 1 (satu) tahun, yang meliputi:

a. Modul Kerohanian, program ini adalah program keagamaan yang dilakukan secara terus menerus sepanjang anak menjalani pidananya adapun modul kerohanian yang dilakukan antara lain kelas fardhu ain dan fardhu kifayah, sembayang berjemaah (sholat berjamaah), bacaan surah yasin (membaca surat yasin), doa diwaktu pagi dan malam, kelas membaca Al Quran, kelas tajwid dan tayangan video (konseling agama).

b. Modul Kaunseling, yang terdiri dari kaunseling individu, kaunseling kelompok/kumpulan, motivasi dan kaunseling keluarga, psikoterapi dan terapi realiti.

c. Modul Akademik, terdiri dari program pendidikan/sekolah mulai dari Peperiksaan Penilaian Menengah Rendah (PMR), Sijil Peperiksaan Malaysia (SPM), dan Sijil Tinggi Persekolahan Malaysia (STPM).

d. Modul Sukan dan Rekreasi (olah raga dan rekreasi), kegiatan ini dilakukan 1 (satu) jam setiap hari, kegiatan olah raga tersebut antara lain bola jarring (basket), ping pong, dan bola tampar (volley ball).

3. Kemahiran dilakukan selama 6 (enam) bulan sampai dengan 1 (satu) tahun. Program kemahiran ini terdiri dari Bengkel jahit, bengkel kraftangan, bengkel batik, bengkel bakeri dan kantin sekolah dan dapur.

4. Pra Bebas dilaksanakan 6 (enam) bulan sampai dengan 1 (satu) tahun. Ini dilaksanakan dan diberikan kepada anak yang dipidana dengan diberikannya cuti sementara selama 7 (tujuh) hari. ${ }^{13}$

Berdasarkan beberapa program pembinaan yang dilakukan di 3 (tiga) lembaga atau institusi penjara bagi anakanak di Malaysia di atas, maka dapat penulis simpulkan bahwa Malaysia mendirikan lembaga pemulihan atau pembinaan bagi anak-anak yang berkonflik dengan hukum dengan menggabungkan 3 (tiga) bentuk program pembinaan yaitu

1. Program pendekatan konseling dan bimbingan.

2. Program pendidikan dan keterampilan.

3. Program rekreasi.

Sejalan hal di atas, Datuk Hassan Sakimon selaku Ketua Pengarah Penjara (Keselamatan dan Koreksional) mengatakan bahwa:

Program kerjasama jabatan penjara sejalan dengan keinginan Kerajaan Bidang Keberhasilan Utama Negara (NKRA) guna mengurangi kejahatan atau tindak pidana yang dilakukan oleh anak-anak. Anak-anak yang berada dalam institusi penjara tidak boleh ketinggalan kesempatan seperti anak-anak lain di luar penjara. Institusi penjara

\footnotetext{
${ }^{11}$ Ibid.

${ }^{12}$ Azizi Yahaya, "Satu Penilaian Terhadap Keberkesanan Perlaksanaan Program di Pusat Pemulihan Akhlak di Semenanjung Malaysia”, Tesis, (Malaysia: Universiti Teknologi Malaysia, 1999) hlm. 2.

${ }^{13}$ Darussalam Budin, "Pendidikan Juvana di Jabatan Penjara Malaysia: Dasar, Hala Tuju, Pelaksanaan dan Cabaran", Jurnal Institut Islam Hadhari, Universiti Kebangsaan Malaysia, Bangi, Selangor, Malaysia tanggal 6 Januari 2014 , hlm. 87.
} 
harus menjadikan mereka sebagai anak-anak yang berguna setelah bebas dari tahanan dan seterusnya lembaga penjara membantu proses pembinaan dan pemulihan selama berada dalam tahanan. ${ }^{14}$

\section{METODE}

Metode penelitian yang digunakan adalah yuridis normatif, difokuskan pada: "asas-asas hukum, sistematika hukum, taraf sinkronisasi hukum, perbandingan hukum dan sejarah hukum. selanjutnya menggunakan pendekatan konseptual, pendekatan perundang-undangan, pendekatan kasus, pendekatan sejarah, pendekatan perbandingan.

\section{HASIL DAN PEMBAHASAN}

\section{Lembaga yang menangani kewenangan pembinaan anak berkonflik dengan hukum di Indonesia dan Malaysia}

Lembaga yang menangani kewenangan pembinaan anak berkonflik dengan hukum di Indonesia adalah Lembaga Pembinaan Khusus Anak (LPKA). Dengan berubahnya nama Lembaga Pemasyarakatan Anak menjadi Lembaga Pembinaan Khusus Anak (LPKA) dengan demikian, maka berubah pulalah model hunian bagi anak berkonflik dengan hukum. Adapun standar hunian di Lembaga Pembinaan Khusus Anak (LPKA) mengacu pada 3 (tiga) aspek yaitu aspek kebutuhan teknis pemasyarakatan, aspek hak anak di dalam proses pemasyarakatan dan aspek bangunan khusus pemasyarakatan. ${ }^{15}$

Pada Akta Kanak-Kanak 2001 terdapat 4 (empat) lembaga yang menangani kewenangan anak berkonflik dengan hukum di Malaysia. Lembaga-lembaga tersebut antara lain:

1. Asrama Akhlak (Probation Hostel)

Asrama Akhlak (Probation Hostel) adalah institusi yang ditetapkan dan ditunjuk oleh Menteri wanita, keluarga dan pengembangan masyarakat sebagai tempat tinggal bagi anak-anak yang diperintahkan oleh Akta Kanak-Kanak 2001. Asrama Akhlak (Probation Hostel) ini merupakan tempat pemulihan bagi anak-anak yang terlibat dengan pidana percobaan. Di Asrama Akhlak (Probation Hostel) ini anak-anak didik dan dibina agar bersikap positif dan diberikan keterampilan.

2. Sekolah Tunas Bakti (STBs)

Sekolah Tunas Bakti (STBs) didirikan untuk pendidikan, pelatihan dan penahanan anak. Sekolah Tunas Bakti (STBs) dibentuk dan ditetapkan oleh Menteri Kebajikan Masyarakat sebagaimana termaktub di dalam Akta Kanakkanak 2001. Sekolah Tunas Bakti (STBs) melayani anak pelanggar hukum, anak tindakan diluar kontrol (beyond control) dan terkadang anak-anak tahanan. ${ }^{16}$

3. Sekolah Henry Gurney (SHG)

Sekolah Henry Gurney (SHG) didirikan oleh Inggris digunakan untuk keperluan mengatasi kejahatan atau tindak pidana anak di Tanah Melayu. Sekolah Henry Gurney (SHG) berada dibawah Jabatan Penjara Malaysia, Kementerian Kebajikan Am dan dibawah pengawasan Kementerian Dalam Negeri. Sekolah Henry Gurney (SHG) dioperasikan oleh Jabatan Kepenjaraan dengan tingkat pengamanan lebih tinggi dari Sekolah Tunas Bakti (STBs). Sekolah Henry Gurney (SHG) adalah institusi pemulihan yang dikelola oleh Jabatan Kepenjaraan Malaysia bagi tahanan anak-anak yang berumur 14 (empat belas) tahun sampai dengan 21 (dua puluh satu) tahun.

4. Sekolah Integriti (SI) atau Juvenile Correctional Centres (JCC)

Institusi ini membina anak laki-laki tahanan dan narapidana berusia 14 (empat belas) tahun sampai dengan 21 (dua puluh satu) tahun. Anak berusia di bawah 18 (delapan belas) tahun ditempatkan terpisah dari anak berusia 18 (delapan belas) tahun sampai dengan 21 (dua puluh satu) tahun, untuk menghindari bullying atau eksploitasi terhadap anak-anak yang lebih kecil. Anak wanita saat ini masih ditempatkan bersama wanita dewasa, walaupun begitu mereka tetap ditempatkan terpisah.

Nama sekolah yang dirikan dalam institusi penjara adalah Sekolah Henry Gurney (SHG) dan Sekolah Integriti. Sekolah Integriti adalah sekolah untuk tahanan anak-anak yang berada dibawah Akta langkah-langkah pencegahan khas Dadah 1985 dan tahanan anak-anak selain dari Akta Kanak-kanak 2000. Sementara itu Sekolah Henry Gurney adalah sekolah yang diperuntukkan bagi tahanan anak-anak terkait Akta Kanak-kanak 2001. ${ }^{17}$

Berdasarkan penjelasan di atas, dapat penulis jelaskan lembaga yang berwenang dalam menangani anak yang berkonflik dengan hukum di Malaysia dilakukan di 3 (tiga) kelembagaan sesuai dengan umur dan masa pidana yang dijatuhkan kepada anak yang berkonflik dengan hukum. selanjutnya jika dilihat dari konsep United Nations Guidance

\footnotetext{
${ }^{14}$ Ibid

${ }^{15}$ Purwo Ardoko, "Pedoman Pemikiran Dalam Rancang Bangun Bangunan LPKA dan LPAS yang Ramah Anak", Pemaparan FGD Penyusunan Kajian Anak yang Berhadapan Dengan Hukum, tanggal 25 Nopember 2015.

${ }^{16}$ Ibid., hlm. 24.

${ }^{17}$ Jabatan Penjara Malaysia, Pekeliling Sektor Pendidikan Jabatan Jabatan Penjara Malaysia Dasar Objektif dan Halatuju Pendidikan di Jabatan Penjara Malaysia, (Malaysia: Penerbit Jabatan Penjara Malaysia, 2009), hlm. 13.
} 
Prison Planning (The Nelson Mandela Rules), kelembagaan yang berwenang menangani anak yang berkonflik dengan hukum di Malaysia dapat penulis jelaskan bahwa indikator pembangunan kelembagaan yang berwenang melakukan pembinaan di Malaysia yaitu Asrama Akhlak, Sekolah Tunas Bakti (STBs), Sekolah Henry Gurney (SHG) dan Sekolah Integriti (SI) sudah mengikuti indikator yang ditentukan oleh United Nations Guidance Prison Planning (The Nelson Mandela Rules).

Persamaan lembaga yang berwenang menangani anak yang berkonflik dengan hukum di Indonesia dan Malaysia, indikatornya antara lain:

1. Aturan/Norma

Aturan/Norma yang mengatur tentang lembaga yang berwenang menangani anak yang bekonflik dengan hukum di Indonesia diatur dalam Undang-Undang Nomor 11 Tahun 2012 tentang Sistem Peradilan Pidana Anak. Di dalam undang-undang ini dijelaskan bahwa lembaga yang berwenang tersebut bernama Lembaga Pembinaan Khusus Anak (LPKA). Sementara itu di Malaysia sendiri, aturan yang mengatur tentang lembaga yang berwenang menangani anak yang berkonflik dengan hukum diatur dalam Akta Kanak-Kanak 2001. Lembaga yang berwenang menangani anak yang berkonflik dengan hukum ditentukan oleh Menteri, adapun jenis-jenis tempat tahanan yang terdapat di Malaysia berdasarkan Akta Kanak-Kanak 2011 antara lain Asrama Akhlak, Sekolah Tunas Bakti, Sekolah Henry Gurney dan Sekolah Integriti. Malaysia terdapat 2 (dua) aturan yang mengatur tentang lembaga yang berwenang menangani anak yang berkonflik dengan hukum yaitu Akta Kanak-Kanak 2001 dan Akta Langkah-langkah Pencegahan Khas Dadah 1985.

2. Lembaga Penanggungjawab operasional.

Persamaan lembaga penanggungjawab operasional antara Indonesia dan Malaysia yaitu sama-sama ada penanggungjawab operasionalnya yaitu Direktorat Jenderal Pemasyarakatan sebagai penangungjawab operasional dari Lembaga Pembinaan Khusus Anak (LPKA). Sedangkan di Malaysia penanggungjawab operasional terdapat 2 (dua) penanggungjawab yaitu Asrama Akhlak dan Sekolah Diluluskan/Sekolah Tunas Bakti (STBs) penanggungjawabnya adalah Jabatan Kebajikan Masyarakat dan Sekolah Henry Gurney (SHG) dan Sekolah Integriti atau Juvenile Correctional Centres (JCC) penanggungjawabnya adalah Jabatan Kepenjaraan Malaysia.

Perbedaan lembaga yang menangani kewenangan anak yang berkonflik dengan hukum di Indonesia dan Malaysia, indikatornya antara lain:

1. Aturan/Norma

Aturan atau norma yang mengatur tentang anak yang berkonflik dengan hukum di Indonesia yaitu Undang-Undang Nomor 11 Tahun 2012 tentang Sistem Peradilan Pidana. Selanjutnya dikatakan di dalam undang-undang ini Lembaga Pembinaan Khusus Anak (LPKA) hanya boleh melakukan pembinaan bagi anak yang berkonflik dengan hukum ketika anak tersebut berumur 14 (empat belas) tahun ke atas. bahwa aturan atau norma lembaga yang berwenang menangani anak yang berkonflik dengan hukum di Malaysia adalah Akta Kanak-Kanak 2001. Di dalam Akta Kanak-kanak ini lembaga yang berwenang menangani anak berkonflik dengan hukum ada 3 (tiga) lembaga. Selanjutnya sebelum anak yang berkonflik dengan hukum dibina oleh Asrama Akhlak, Sekolah Diluluskan/Sekolah Tunas Bakti (STbs) dan Sekolah Henry Gurney (SHG), yang menentukan anak yang berkonflik dengan hukum di Malaysia ditempatkan ditempat tahanan adalah Mahkamah bagi Kanak-Kanak.

2. Lembaga

Di Indonesia lembaga penanggungjawab operasional Lembaga Pembinaan Khusus Anak (LPKA) adalah Direktorat Jenderal Pemasyarakatan pada Kementerian Hukum dan Hak Asasi Manusia. Sedangkan di Malaysia lembaga penanggungjawab operasional terbagi 2 (dua) yaitu Jabatan Kebajikan Masyarakat sebagai penanggungjawab operasional dari Asrama Akhlak dan Sekolah Diluluskan/Sekolah Tunas Bakti (STBs) dan Jabatan Kepenjaraan Malaysia sebagai penanggungjawab operasional dari Sekolah Henry Gurney (SHG) dan Sekolah Integriti (SI) atau Juvenile Correctional Centres (JCC). ${ }^{18}$

Kelemahan lembaga yang berwenang menangani anak yang berkonflik dengan hukum di Indonesia antara lain:

1. Kelemahan dan keunggulan dari lembaga yang berwenang menangani anak yang berkonflik dengan hukum di Indonesia sebagai berikut. Kelemahan lembaga yang menangani kewenangan anak berkonflik dengan hukum di Indonesia dapat dilihat dari peraturan perundang-undangannya yaitu Undang-Undang Nomor 11 Tahun 2012 tentang Sistem Peradilan Pidana Anak hanya mengatur secara umum tentang Lembaga Pembinaan Khusus Anak (LPKA), undang-undang ini tidak mengatur secara spesifik tentang konsep hunian di dalam Lembaga Pembinaan Khusus Anak (LPKA) dan Lembaga Penempatan Anak Sementara (LPAS) dan undang-undang ini sampai dengan saat ini tidak tidak diatur oleh peraturan pelaksananya. Kemudian keunggulan dari undang-undang ini antara lain:

\footnotetext{
${ }^{18}$ Nurini Aprilianda, dkk, "Laporan Akhir Pengkajian Huum tentang Model Pembinaan Anak Berbasis Pendidikan Layak Anak Dalam Sistem Pemasyarakatan”, Pusat Penelitian dan Pengembangan Sistem Hukum Nasional BPHN Kementerian Hukum dan HAM, Jakarta, 2014, hlm. 102
} 
Undang-Undang Nomor 11 Tahun 2012 tentang Sistem Peradilan Pidana Anak mengkhususkan anak dijatuhi piidana atau anak yang berkonflik dengan hukum "wajib" dibina di dalam Lembaga Pembinaan Khusus Anak (LPKA) dan Undang-Undang ini juga mengatur tentang pendirian Lembaga Penempatan Anak Sementara (LPAS) dan Lembaga Penyelenggaraan Kesejahteraan Sosial (LPKS).

2. Kelemahan dan keunggulan lembaga yang berwenang menangani anak yang berkonflik dengan hukum di Malaysia. Adapun kelemahan lembaga yang menangani anak berkonflik dengan hukum di Malaysia adalah Akta Kanak-Kanak 2001 mengatur secara umum tentang lembaga yang menangani anak berkonflik dengan hukum di Malaysia dan Akta Kanak-Kanak 2001 tidak mengatur secara spesifik tentang konsep hunian bagi lembaga yang menangani anak berkonflik dengan hukum di Malaysia. Selanjutnya keunggulan dari peraturan perundangundangan Malaysia adalah Akta Kanak-Kanak 2001 membagi 3 (tiga) lembaga yang menangani anak yang berkonflik dengan hukum, Akta Langkah-langkah Pencegahan Khas Dadah 1985 merupakan peraturan perundangundangan yang mengatur tentang lembaga yang menangani anak berkonflik dengan hukum yang terlibat narkotika dan psikotropika dan Akta Kanak-Kanak 2001 mengatur penanggungjawab operasional masing-masing lembaga yang menangani kewenangan anak yang berkonflik dengan hukum di Malaysia.

\section{Pembinaan Anak yang Berkonflik dengan Hukum di Indonesia dan Malaysia dari Perspektif Restorative Justice}

Sejak lahirnya Undang-Undang Nomor 11 Tahun 2012 tentang Sistem Peradilan Pidana Anak, pembinaan anak berkonflik dengan hukum semestinya pembinaan anak berkonflik dengan hukum berdasarkan undang-undang ini, namun sampai dengan saat ini pembinaan anak berkonflik dengan hukum masih menggunakan amanat yang terkandung didalam Undang-Undang Nomor 12 Tahun 1995 tentang Pemasyarakatan dan Peraturan Pemerintah Nomor 31 Tahun 1999 tentang Pembinaan dan Pembimbingan Warga Binaan Pemasyarakatan. Hal ini dikarenakan sampai dengan saat ini belum ada peraturan pemerintah sebagai pelaksanaan Undang-Undang Nomor 11 Tahun 2012 tentang Sistem Peradilan Pidana Anak.

Anak yang telah mendapatkan putusan Pengadilan dengan dijatuhi pidana penjara di tempatkan di Lembaga Pembinaan Khusus Anak (LPKA). Anak tersebut disebut dengan anak yang berkonflik dengan hukum. Selanjutnya anak ini wajib memperoleh pelayanan, perawatan, pendidikan dan pelatihan, pembimbingan dan pendampingan serta hak lain sesuai dengan ketentuan peraturan perundang-undangan. Pemenuhan hak-hak anak yang berkonflik dengan hukum inilah yang merupakan kewajiban bagi Lembaga Pembinaan Khusus Anak selama melakukan pembinaan dan pembimbingan bagi anak yang berkonflik dengan hukum.

1. Tahap Admisi, Orientasi dan Observasi

Selama proses penerimaan berlangsung, petugas Lembaga Pembinaan Khusus Anak (LPKA) wajib mengedepankan perlakuan yang ramah, menghormati harkat, martabat dan hak anak.

2. Tahap Pembinaan Awal

Tahap pembinaan awal dimulai sejak anak baru diterima di Lembaga Pembinaan Khusus Anak (LPKA) hingga 1/3 (satu pertiga) masa pidana atau batas waktu yang ditentukan berdasarkan hasil Penelitian Kemasyarakatan (Litmas). Dalam pembinaan awal yang dilakukan oleh Lembaga Pembinaan Khusus Anak (LPKA) kepada anak yang berkonflik dengan hukum, jika dilihat dari sudut pandang keadilan restoratif, pembinaan ini hanya dilakukan oleh lembaga pembinaan dengan anak yang berkonflik dengan hukum selaku pelaku tindak pidana. Pada pembinaan awal ini pihak lembaga pembinaan tidak melibatkan korban, keluarga korban, keluarga pelaku maupun mmasyarakat. Pembinaan tahap awal ini lebih kepada pembinaan institusional.

3. Tahap Pembinaan Lanjutan

Pembinaan lanjutan bagi anak yang berkonflik dengan hukum dilakukan dengan melakukan pembauran anak yang berkonflik dengan hukum dengan masyarakat melalui asimilasi. Asimilasi yang diberikan baik asimilasi di dalam maupun asimilasi di luar lembaga. Pada pembinaan tahap lanjutan Lembaga Pembinaan Khusus Anak (LPKA) telah mengajak keluarga pelaku dan masyarakat dalam tahap pembinaannya, misalnya pada tahap pembinaan lanjutan ini pihak keluarga pelaku diberikan kesempatan setiap minggunya melakukan bezukan atau kunjungan kepada anak yang berada di lembaga pembinaan. Dalam pembinaan lanjutan ini, jika anak memenuhi syarat yang ditentukan dapat memperoleh asimilasi keluar dari lembaga pembinaan guna melakukan pembauran dengan masyarakat, misalnya kegiatan lomba pertandingan olah raga yang pesertanya berasal dari masyarakat disekitar lembaga pembinaan. Pada pembinaan lanjutan ini juga tidak terlihat adanya keterlibatan korban maupun keluarga korban dalam tahapan pembinaan yang dilakukan bagi anak yang berkonflik dengan hukum.

4. Tahap Pembinaan Akhir

Pembinaan akhir dilakukan di luar lembaga yaitu dijalankan oleh Balai Pemasyarakatan. Hal ini disebabkan anak yang berkonflik dengan hukum sudah berada di luar Lembaga Pembinaan Khusus Anak (LPKA) oleh karenanya pembinaan lebih lanjut dilakukan oleh Balai Pemasyarakatan. Pembinaan akhir bagi anak yang berkonflik dengan hukum ini dikenal dengan nama pembimbingan. Tahap pembinaan akhir ini dilakukan oleh Balai Pemasyarakatan 
bukan lagi tanggungjawab dari Lembaga Pembinaan Khusus Anak (LPKA). Pada pembinaan tahap akhir ini jika dilihat dengan teori keadilan restoratif, maka pihak-pihak yang turut serta dalam pembinaan bagi anak yang berkonflik dengan hukum antara lain pelaku tindak pidana sendiri yaitu anak yang berkonflik dengan hukum sendiri, keluarga pelaku yang turut sebagai penanggungjawab atau penjamin, masyarakat dimana anak menjalani kehidupannya diluar lembaga yang siap menerima kembali jika anak dilakukan pembinaan diluar kelembagaan dan pihak Balai Pemasyarakatan yang terdiri dari Pembimbing Kemasyarakatan selaku pembina bagi anak yang berkonflik dengan hukum di luar kelembagaan. Di dalam pembinaan akhir ini juga tidak terlihat keterlibatan korban dan keluarga korban pada pembinaan anak yang berkonflik dengan hukum.

Penanganan kejahatan yang terjadi tidak hanya menjadi tanggungjawab negara akan tetapi juga merupakan tanggungjawab masyarakat. Oleh karena itu konsep keadilan restoratif dibangun berdasarkan pengertian kerugian yang ditimbulkan oleh kejahatan akan dipuluhkan kembali, baik kerugian yang diderita oleh korban maupun kerugian yang ditanggung oleh masyarakat. Pelaksanaan konsep keadilan restoratif memberi banyak kesempatan kepada masyarakat untuk berperan aktif dalam penyelesaian masalah tindak pidana. Pada pelaksanaannya anak yang berkonflik dengan hukum yang sedang menjalani masa pembinaan harus terus diusahakan agar dapat tercapai hubungan baik dengan korban maupun keluarga korban sehingga pembinaan anak yang berkonflik dengan hukum harus diarahkan pada rehabilitasi dan resosialisasi pelaku.

Dalam konsep kepenjaraan di Malaysia, penjara merupakan tempat untuk penghuni ditahan, dikawal dan menjalani berbagai aktivitas pemulihan yang disediakan sehinggalah sampai masa mereka dibebaskan. Jabatan Penjara Malaysia bertanggungjawab untuk melaksanakan rawatan dan pemulihan yang berkesan kepada penghuni supaya mereka menjadi ahli keluarga, ahli masyarakat dan warganegara yang berguna seterusnya tidak lagi melakukan tindak pidana atau kejahatan. Jabatan Penjara Malaysia adalah institusi terakhir dalam sistem peradilan pidananya. Program pemulihan melibatkan tahanan dengan menggunakan pendidikan melalui sistem persekolahan adalah merupakan program Jabatan Kepenjaraan Malaysia dan Kementerian Pelajaran Malaysia. ${ }^{19}$ Pendidikan ialah suatu proses membentuk individu yang berakhlak mulia. masalah ini selaras dengan fase pengukuhan sahsiah proses pemulihan penghuni di Jabatan Penjara Malaysia iaitu membina akhlak. ${ }^{20}$

Pemulihan penghuni di penjara menggunakan "Program Pembangunan Insan" dilancarkan pada Tahun 2004. Program ini mempunyai 4 (empat) fase yaitu fase pembentukan disiplin, fase pengukuhan sahsiah, fase kemahiran dan fase pemasyarakatan. Fase Pengukuhan Sahsiah untuk juvana Kanak-Kanak menggunakan "Modul Putra". Program pemulihan di sekolah penjara bertujuan untuk memberikan pendidikan formal serta memperbaiki nilai-nilai murni penghuni supaya mereka dapat diterima semula oleh masyarakat. ${ }^{21}$

Setiap tahanan anak diwajibkan mendapatkan program pendidikan selama mereka menjalani pidananya. Selanjutnya pendidikan di dalam penjara ini merupakan program kerjasama antara Jabatan Penjara Malaysia dan Kementerian Pelajaran Malaysia. Kemudian pembinaan anak yang berkonflik dengan hukum di Malaysia dilakukan oleh Jabatan Kepenjaraan Malaysia dengan "Program Pembangunan Insan" atau dikenal dengan "Modul Putra", untuk kegiatan rehabilitasi integrasi bagi anak berkonflik dengan hukum. Di dalam modul putra ini dilalui dengan 4 (empat) fase, yaitu:

1. Fase Pertama, 2 (dua) bulan yaitu Orientation and Discipline Building.

Pada tahap ini anak-anak diarahkan untuk mengerti peraturan sekolah dan mengikuti kegiatan kewarganegaraan dan pendidikan keagamaan, juga kegiatan baris berbaris untuk membangun kedisiplinan. ${ }^{22}$

2. Fase Kedua, 6 (enam) sampai dengan 12 (dua belas) bulan yaitu Character Reinforcement.

Fase ini menerapkan model "Therapeutic Community (TC)" untuk pengembangan kepribadian. Pada tahap ini termasuk juga sesi konseling, pendidikan moral, komunikasi keagamaan dan pendidikan akademik. Program akademik mengikuti kurikulum yang berlaku di sekolah negeri, dengan guru guru yang ditunjuk oleh Kementerian Pendidikan. ${ }^{23}$

3. Fase Ketiga, 6 (enam) sampai 12 (dua belas) bulan yaitu Skill Building.

Pada fase ini, anak laki-laki dapat memilih program pelatihan keterampilan bersertifikat melalui Malaysian Skill Certificate atau Program CIDB. Program-programnya adalah Pengelasan, penjahitan, kelistrikan, konstruksi, pertamanan, maupun kegiatan keterampilan yang tidak bersertifikat, seperti laundry, pertukangan dan memasak.

${ }^{19}$ Darussalam Budin, "Pendidikan Juvana diJabatan Penjara Malaysia: Dasar, Hala Tuju, Pelaksanaan dan Cabaran”, Institut Islam Hadhari, Universitas Kebangsaan Malaysia, Bangi, Selangor, Malaysia, Jurnal Hadhari, (6 Januari 2014 ), hlm. 87.

${ }^{20}$ Ibid.

${ }^{21}$ Ibid.

${ }^{22}$ Ibid

${ }^{23}$ Ibid. 
Untuk anak-anak wanita sekolah menawarkan kursus pertamanan, memasak, mejahit dan batik. Kegiatan keagamaan, konseling dan olahraga terus berlanjut pada tahap ini. ${ }^{24}$

4. Fase Keempat, 6 (enam) bulan.

Pada tahap ini anak-anak disiapkan untuk reintegrasi ke dalam masyarakat dengan bekerja sukarela di luar institusi sekolah. Setiap anak-anak di Sekolah Henry Gurney (SHG) memiliki dokumen pribadi dan setiap perkembangannya dicatat, dievaluasi setiap 3 (tiga) bulan. Di luar kegiatan keterampilan, secara umum anak-anak mengikuti program pembinaan yang sama. Semua personil sekolah telah mendapatkan pelatihan konseling, namun tetap saja mereka belum cukup keahlian untuk menjalankan pembinaan secara individu atau pendekatan perubahan perilaku. Semua staf mendapatkan pelatihan umum melalui Akademi Koreksional, namun tidak mendapatkan pelajaran spesifik tentang "Modul Putra" untuk menangani narapidana/tahanan anak. ${ }^{25}$

Persamaan proses pembinaan anak yang berkonflik dengan hukum di Indonesia dan Malaysia, indikatornya antara lain:

1. Aturan/Norma Pembinaan Anak Berkonflik Dengan Hukum.

Aturan atau norma yang mengatur pembinaan anak berkonflik dengan hukum di Indonesia terdiri dari 3 (tiga) aturan yaitu Undang-Undang Nomor 11 Tahun 2012 tentang Sistem Peradilan Pidana Anak, Undang-Undang Nomor 12 Tahun 1995 tentang Pemasyarakatan dan Peraturan Pemerintah Nomor 31 Tahun 1999 tentang Pembinaan dan Pembimbingan. Sementara di Malaysia aturan atau norma yang mengatur tentang pembinaan anak yang berkonflik dengan hukum diatur dengan 3 (tiga) aturan atau norma yaitu Akta Kanak-Kanak 2001, Akta Penjara 2000 dan Peraturan Sekolah Henry Gurney (SHG) 1949.

2. Program Pembinaan Anak yang Berkonflik Dengan Hukum

Program pembinaan bagi anak yang berkonflik dengan hukum di Indonesia diatur dalam Undang-Undang Nomor 11 Tahun 2012 tentang Sistem Peradilan Pidana Anak, adapun program pembinaan yang dilaksanakan yaitu program pembinaan dan pembimbingan. Program pembinaan ini dilaksanakan di Lembaga Pembinaan Khusus Anak (LPKA) sementara program pembimbingan dilaksanakan oleh Balai Pemasyarakatan (BAPAS). Sementara itu program pembinaan bagi anak yang berkonflik dengan hukum di Malaysia diatur dalam Akta Kanak-kanak 2001. Program pembinaan yang diberikan kepada anak yang berkonflik dengan hukum adalah program pembangunan insan. Program pembangunan insan ini terdiri dari program akademik, ko-kurikulum, keagamaan, bimbingan dan konseling.

3. Tahapan Pembinaan

Tahapam pembinaan anak yang berkonflik dengan hukum di Indonesia dilakukan dengan 3 (tiga) tahapan. Adapun tahapan pembinaan tersebut yaitu tahap awal, tahap lanjutan dan tahap akhir. sementara tahapan pembinaan bagi anak yang berkonflik dengan hukum di Malaysia diatur dalam peraturan Sekolah Henry Gurney 1949. Adapun tahapan pembinaannya adalah fase I ( 2 bulan) disebut dengan fase pembentukan disiplin, fase II (6-12 bulan) disebut fase pengukuhan sahsiah, fase III (6-12 bulan) disebut fase kemahiran dan fase IV (6 bulan) disebut fase pemasyarakatan.

berikut:

Perbedaan proses pembinaan anak yang berkonflik dengan hukum di Indonesia dengan Malaysia adalah sebagai

1. Aturan/norma pembinaan anak yang berkonflik dengan hukum.

Pembinaan bagi anak yang dijatuhi pidana penjara di Indonesia diatur dalam Undang-Undang Nomor 11 Tahun 2012 tentang Sistem Peradilan Pidana Anak tidak menjelaskan secara eksplisit tentang pembinaan bagi anak yang dijatuhi pidana penjara di Lembaga Pembinaan Khusus Anak (LPKA). Sementara pembinaan bagi anak yang dijatuhi pidana penjara di Malaysia diatur dalam Akta Kanak-kanak 2001 dan Peraturan Sekolah Henry Gurney. Pengaturan di dalam aturan tersebut hanya mengkhususkan untuk anak yang sedang menjalani pidana penjara

2. Program pembinaan anak berkonflik dengan hukum

Program pembinaan dan pembimbingan bagi anak yang berkonflik dengan hukum diperuntukan bagi Warga Binaan Pemasyarakatan (WBP). Adapun yang termasuk Warga Binaan Pemasyarakatan (WBP) ini adalah narapidana dewasa dan anak didik pemasyarakatan. Sementara itu program pembinaan bagi anak yang berkonflik dengan hukum di Malaysia tidak diatur dalam Akta Kanak-kanak 2001. Pengaturan tentang program pembinaan bagi anak berkonflik dengan hukum di Malaysia diatur dalam Peraturan Sekolah Henry Gurney 1949. bahwa program pembinaan pembangunan insan yang diperuntukan bagi anak yang berkonflik dengan hukum di Malaysia terdiri dari pendidikan akademik, pendidikan ko-kurikulum, pendidikan keagamaan, bimbingan dan konseling. Program pembangunan insan ini hanya diberikan kepada Juvana Kanak-Kanak.

\footnotetext{
${ }^{24}$ Ibid.

${ }^{25}$ Ibid.
} 
3. Tahapan pembinaan anak yang berkonflik dengan hukum.

Tahapan pembinaan bagi anak yang berkonflik dengan hukum dimulai pada masa (0-1/3) atau yang lebih dikenal dengan pembinaan tahap awal, pada tahap ini dilakukan beberapa kegiatan. Selanjutnya pada masa (1/3-1/2) atau tahapan lanjutan dilakukan beberapa kegiatan dan yang terakhir masa (1/2-bebas) atau tahap akhir dilakukan beberapa kegiatan. Selanjutnya tahapan pembinaan bagi anak yang berkonflik dengan hukum di Malaysia diatur dalam peraturan Sekolah Henry Gurney 1949. Adapun proses atau tahapan pembinaannya adalah fase I (2 bulan), fase II (6-12 bulan), fase III (6-12 bulan) dan fase IV (6 bulan).

Kelemahan pembinaan anak yang berkonflik dengan hukum di Indonesia adalah sejak lahirnya Undang-Undang Nomor 11 Tahun 2012 tentang Sistem Peradilan Pidana sampai dengan saat ini belum ada aturan pelaksana dari undang-undang ini, pembinaan yang diberikan kepada anak yang berkonflik dengan hukum masih berpedoman dengan Undang-Undang Nomor 12 Tahun 1995 tentang Pemasyarakatan dan Peraturan Pemerintah Nomor 31 Tahun 1999 tentang Pembinaan dan Pembimbingan Warga Binaan Pemasyarakatan. Program pembinaan dalam undangundang ini sama dengan program pembinaan narapidan dewasa dengan anak didik pemasyarakatan (WBP), dan tahapan pembinaan yang ada saat ini sama dengan tahapan pembinaan yang diberikan kepada narapidana dewasa.

Keunggulan pembinaan anak yang berkonflik dengan hukum di Indonesia adalah di dalam Undang-Undang Nomor 11 Tahun 2012 tentang Sistem Peradilan Pidana Anak, Undang-Undang Nomor 12 Tahun 1995 tentang Pemasyarakatan dan Peraturan Pemerintah Nomor 31 Tahun 1999 tentang Pembinaan dan Pembimbingan Warga Binaan Pemasyarakatan dijelaskan dan diatur tentang Program pembinaan dan tahapan pembinaan bagi anak yang berkonflik dengan hukum di LPKA.

Kelemahan pembinaan anak yang berkonflik dengan hukum di Malaysia adalah Akta Kanak-Kanak 2001, Akta Penjara 2000 hanya mengatur tentang program pembinaan yang wajib diberikan kepada anak jika dipidana penjara, namun Akta-Akta tersebut tidak mengatur tentang proses/tahapan dalam pembinaan yang dilakukan. Sedangkan keunggulan dari proses pembinaan anak yang berkonflik dengan hukum di Malaysia adalah pengaturan tentang program pembinaan bagi anak yang berkonflik dengan hukum di Malaysia diatur dalam Akta Kanak-Kanak 2001, Akta Penjara 2000 dan program pembinaan yang dijalankan bagi anak yang berkonflik dengan hukum di Malaysia adalah program pembangunan insan dengan memfokuskan pada pendidikan dan konseling.

\section{SIMPULAN}

1. Kelembagaan yang berwenang menangani anak yang berkonflik dengan hukum di Indonesia adalah Lembaga Pembinaan Khusus Anak (LPKA) sedangkan kelembagaan yang berwenang menangani anak yang berkonflik dengan hukum di Malaysia adalah Asrama Akhlak, Sekolah Tunas Bakti (STBs) dan Sekolah Henry Gurney (SHG). Selanjutnya dari sudut tanggungjawab pembinaan anak yang berkonflik dengan hukum tersebut terdapat perbedaan antara Indonesia dan Malaysia yaitu penanggungjawab Lembaga Pembinaan Khusus Anak (LPKA) adalah Direktorat Jenderal Pemasyarakatan sedangkan di Malaysia penanggungjawab Asrama Akhlak dan Sekolah Tunas Bakti (STBs) adalah Jabatan Kebajikan Masyarakat dan penanggungjawab Sekolah Henry Gurney (SHG) adalah Jabatan Kepenjaraan Malaysia. Kemudian dari kelembagaan ini terdapat persamaan antara Indonesia dan Malaysia yaitu kelembagaan yang menangani anak berkonflik dengan hukum mempunyai tujuan yang sama yaitu mencapaian kepastian, kemanfaatan dan keadilan demi mewujudkan kelembagaan pembinaan anak yang berkonflik dengan hukum yang mempertimbangkan penghormatan harkat dan martabat anak dalam bentuk perspektif struktur menjadi kelembagaan yang layak anak.

2. Pembinaan bagi anak berkonflik dengan hukum di Indonesia diatur dalam Undang-Undang Nomor 11 Tahun 2012 tentang Sistem Peradilan Pidana Anak, Undang-Undang Nomor 12 Tahun 1995 tentang Pemasyarakatan sedangkan pembinaan bagi anak berkonflik dengan hukum di Malaysia diatur dalam Akta Kanak-Kanak 2001. Pembinaan anak yang berkonflik dengan hukum di Indonesia dikenal dengan "Program pembinaan dan pembimbingan" yang terdiri dari pembinaan kepribadian dan pembinaan kemandirian sedangkan pembimbingan yaitu integrasi ke masyarakat berupa pembebasan bersyarat, cuti bersyarat. Sementara di Malaysia pembinaan anak yang berkonflik dengan hukum dikenal dengan "Program pembangunan insan". Program ini terdiri dari program akademik, ko-kurikulum, keagamaan dan bimbingan dan konseling. Selanjutnya tahapan/proses pembinaan yang diterapkan di Indonesia bagi anak yang berkonflik dengan hukum adalah 3 (tiga) tahap yaitu tahap awal $(0-1 / 3)$, tahap lanjutan (1/3-1/2) dan tahap akhir (1/2-bebas) sementara itu di Malaysia tahap/proses pembinaan yang diterapkan kepada anak yang berkonflik dengan hukum dengan 4 (empat) tahap yaitu Fase I (2 bulan): fase pembentukan disiplin, fase II (6-12 bulan): fase pengeukuhan sahsiah, fase III: (6-12 bulan): fase kemahiran dan fase IV ( 6 bulan): fase pemasyarakatan. Persamaan pembinaan yang dilakukan bagi anak yang berkonflik dengan hukum antara Indonesia dan Malaysia adalah sama-sama dilakukan pembinaan di dalam lembaga pembinaan khusus bagi anak yang berkonflik dengan hukum. Dalam hal pihak-pihak yang terlibat dalam pembinaan anak yang berkonflik dengan hukum antara Indonesia dan Malaysia terdapat perbedaan Indonesia pihak yang terlibat dalam 
pembinaan anak yang berkonflik dengan hukum dilakukan oleh institusi lembaga pembinaan, pelaku, keluarga pelaku dan masyarakat sedangkan Malaysia pihak yang terlibat dalam pembinaan anak yang berkonflik dengan hukum telah melibatkan institusi lembaga pembinaan, pelaku, keluarga pelaku, korban, keluarga korban dan masyarakat. Selanjutnya pembinaan anak yang berkonflik dengan hukum sesuai dengan konvensi internasional adalah pembinaan anak yang berkonflik dengan hukum dari sudut perspektif restoratif justice atau keadilan restoratif.

\section{DAFTAR PUSTAKA}

\section{Buku:}

Kurniasari Alit, dkk, Studi Penanganan Anak Yang Berkonflik Dengan Hukum, Puslitbang Kessos, Jakarta: Depsos Republik Indonesia, 2007

Utomo, Hadi, Anak Yang Berkonflik Dengan Hukum, Jakarta: Yayasan Bahtera-Unesco-Unicef, 2010

Muncie, Jhon, Youth and Crime A Critical Introduction, (London:Sage Publibation, 1999

Jabatan Penjara Malaysia, Pekeliling Sektor Pendidikan Jabatan Jabatan Penjara Malaysia Dasar Objektif dan Halatuju Pendidikan di Jabatan Penjara Malaysia, Malaysia: Penerbit Jabatan Penjara Malaysia, 2009

\section{Jurnal/Artikel:}

Yahaya, Azizi, "Satu Penilaian Terhadap Keberkesanan Perlaksanaan Program di Pusat Pemulihan Akhlak di Semenanjung Malaysia", Tesis, Malaysia: Universiti Teknologi Malaysia, 1999

Rusmana, Aep, "Alternatif perlindungan Anak yang Berkonflik Dengan Hukum”, Jurnal Pusdiklat Kesos, Volume 1, Bandung, (Agustus 2008)

Kania, Dinar dan Ahmad Alim, "Stategi Pembinaan Pendidikan Berbasis Psikologi Pendidikan", Artikel (30 September 2012):

Budin, Darussalam, "Pendidikan Juvana di Jabatan Penjara Malaysia: Dasar, Hala Tuju, Pelaksanaan dan Cabaran", Jurnal Institut Islam Hadhari, Universiti Kebangsaan Malaysia, Bangi, Selangor, Malaysia tanggal 6 Januari 2014

Ardoko, Purwo, "Pedoman Pemikiran Dalam Rancang Bangun Bangunan LPKA dan LPAS yang Ramah Anak", Pemaparan FGD Penyusunan Kajian Anak yang Berhadapan Dengan Hukum, tanggal 25 Nopember 2015

Aprilianda, Nurini, dkk, "Laporan Akhir Pengkajian Huum tentang Model Pembinaan Anak Berbasis Pendidikan Layak Anak Dalam Sistem Pemasyarakatan", Pusat Penelitian dan Pengembangan Sistem Hukum Nasional BPHN Kementerian Hukum dan HAM, Jakarta, 2014

\section{Peraturan Perundang-undangan:}

Pesuruh Jaya Penyemak Undang-Undang Malaysia, Akta Kanak-kanak 2001 (Akta 2001), Percetakan Nasional Malaysia BHD , Kuala Lumpur, 2006

Republik Indonesia, Undang-Undang Nomor 12 Tahun 1995 tentang Pemasyarakatan (Lembaran Negara Republik Indonesia Tahun 1995 Nomor 77, Tambahan Lembaran Negara Republik Indonesia Nomor 3614).

Republik Indonesia, Undang-Undang Nomor 11 Tahun 2012 tentang Sistem Peradilan Pidana Anak (Lembaran Negara Republik Indonesia Tahun 2012 Nomor 153, Tambahan Lembaran Negara Republik Indonesia Nomor 5332). 